\title{
Effect of Different Organic Supplements for Production of Milky Mushroom (Calocybe indica P\&C) in Odisha
}

\author{
Niranjan Chinara $^{1 *}$ and Shyama Sundar Mahapatra ${ }^{2}$ \\ ${ }^{1}$ All India Coordinated Research Project on Mushroom, OUAT, \\ Bhubaneswar, Odisha-751003, India \\ ${ }^{2}$ Regional Research and Technology Transfer Station, Ranital, \\ Bhadrak, Odisha- 756111, India \\ *Corresponding author
}

\section{Keywords}

Milky Mushroom (Calocybe indica) Organic

supplements

Article Info

Accepted:

20 June 2020

Available Online:

10 July 2020

\begin{abstract}
A B S T R A C T
Milky mushroom (Calocybe indica $\mathrm{P} \& \mathrm{C}$ ) is one of the tropical, edible mushroom cultivated in India. Its white attractive colour with excellent keeping quality, ability to grow on wide range of agricultural wastes, high conversion rate and above all, its suitability for value addition have made it popular among all the edible mushrooms in recent times. It is very much essential to increase the productivity of mushroom by applying extra supplements during cropping period. For that purpose the experiment was conducted to observe effect of different supplement on productivity of milky mushroom. Therefore, seven different organic supplements viz: wheat bran, boiled wheat, rice bran, maize meal, bengal gram, groundnut cake and chicken manure were added @ 5 per cent of dry substrate individually during preparation of milky mushroom bags. Early spawn run (17.5 d) was observed in the substrate supplemented with maize meal followed by boiled wheat $(20.0 \mathrm{~d})$. Yield of mushroom per bag varied from $1106.7 \mathrm{~g}$ to $1266.7 \mathrm{~g}$ and highest yield of mushroom (1266.7 g) was obtained from the substrate supplemented with groundnut cake. The B : C ratio of mushroom bag without any additives was highest (1.38) followed by rice bran (1.36) and groundnut cake (1.32). There was significant increase in morphometric of mushroom may be due to presence of carbohydrate, amino acid and minerals in different additives applied.
\end{abstract}

\section{Introduction}

Among food, mushrooms have been used for thousands of years because of their delicious flavour and were often used in religious ceremonies. However, use of mushrooms for various purposes was documented in different ancient literatures of Greek and Roman. Mushrooms were earlier preferred for their taste and flavour but later recognised for their nutritive value. Mushrooms are the fruiting body of macro fungus, lack of chlorophyll and derive their food from complex organic materials found in dead or living tissues of plants and animals. There are about 300 species of edible mushrooms belonging to 70 genera reported in India. At present, about 100 countries including India producing more 
than 380 lakh tons of mushrooms annually which has increased from 49.09 lakh tons in the year, 1994. Total mushroom produced in India comprising of five different mushrooms such as button mushroom (Agaricus spp), oyster mushroom (Pleurotus spp), straw mushroom (Volvariella volvacea,) milky mushroom (Calocybe indica) and shiitake (Lentinula edodes) that contributing less than one per cent of world's production. Calocybe indica $\mathrm{P} \& \mathrm{C}$ is one of the tropical mushroom, reported first time from West Bengal, India (Purkayastha, 1974). It is popularly known as milky mushroom because of its milky white colour. Its white attractive colour with excellent keeping quality, ability to grow on wide range of agricultural wastes, high conversion rate and above all, its suitability for value addition have made it popular among all the edible mushrooms in recent times. Therefore, it is essential to increase the productivity of mushroom by applying extra supplements during cropping period. For that purpose the experiment was conducted to observe effect of different supplement on productivity of milky mushroom.

\section{Materials and Methods}

The experiment was conducted in the Centre of Tropical Mushroom Research and Training (CTMRT), Odisha University of Agriculture and Technology (OUAT), Bhubaneswar, Odisha, India. The milky mushroom strain (OCI 04) was used as test fungus during the experiment.

\section{Preparation of Spawn}

Master spawn / Mother spawn of the milky mushroom was prepared from the pure culture of the same. Clean, healthy and bold wheat grains were selected, washed and boiled in a container till they soften. Boiled grains were spread over clean polythene sheet in order to drain out excess water and air dried under shade. Powder of calcium carbonate @ $2 \%$ on dry weight basis of wheat grain was mixed thoroughly to absorb excess moisture as well as maintain proper $\mathrm{pH}$ of the grain. The boiled and treated grains were filled $3 / 4^{\text {th }}$ of $375 \mathrm{ml}$ capacity bottle, plugged with non absorbent cotton and sterilised in autoclave for 2 hours at 22 psi. The sterilised wheat bottles were inoculated with pure culture of milky mushroom and incubated for 15 days to get mother spawn.

\section{Preparation of mushroom bags}

For preparation of milky mushroom bags dry paddy straw were collected, chopped into 2$4 \mathrm{~cm}$ size, soaked in clean water for six hours and excess water was drained. The soaked substrate was pasteurised by means of hot water and dried under shade to maintain substrate moisture about 50-55 \%. About 1.5 $\mathrm{kg}$ substrate was filled in a polythene bag with $10 \%$ spawn applied in layer method. During preparation of milky mushroom bags seven different organic supplements viz: wheat bran, boiled wheat, rice bran, maize meal, bengal gram, groundnut cake and chicken manure were added @ 5 per cent of dry substrate individually. All the supplements were sterilised in autoclave at 15 psi for 15 min and applied along with spawn. Bags raised without any organic supplements were treated as control. Each supplement was replicated thrice with five bags per replication. Then about 10-20 small holes were made in all side of the bag for exchange of gases. The prepared bags were then incubated in dark room at a temperature of $25-35^{\circ} \mathrm{C}$ for spawn run and after that the colonised bags were transferred to cropping room for application of casing soil. Casing material was prepared by mixing garden soil and 2 years old FYM in order to provide physical support as well as to maintain moisture. 
All the prepared bags were subjected to the ambient condition during experiment. The experiment was conducted once in a year from 2014 to 2016 and the pooled data are given below. Data on days to spawn run, days to pin head formation, number of mushrooms, yield per bag and biological efficiency were recorded and analysed in Randomized Block Design (RBD). Similarly, pileus diameter, stipe length and stipe diameter were recorded from five randomly selected mushrooms of each treatment.

\section{Biological efficiency}

The productivity of mushrooms from different substrates was presented in terms of Biological Efficiency (BE) and calculated using following formula.

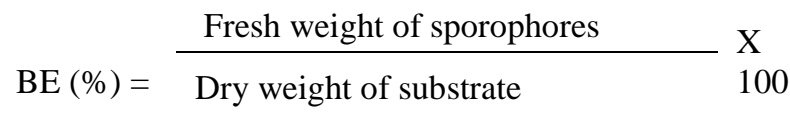

\section{Results and Discussion}

Applications of organic supplements during spawning help not only in increasing the productivity of mushroom but also improve the yield attributing parameters. Therefore, seven different organic supplements were evaluated to study their effect on milky mushroom production. Data recorded on days to spawn run, days to pin head initiation, days to first harvest, biological efficiency, average number of mushrooms, yield per bag, B:C ratio and yield attributing parameters are presented in table 1 and 2 separately.

Perusal of data from table 1 indicated that, days to spawn run varied from 17.5 to 24.1 days. Earliest spawn run $(17.5 \mathrm{~d})$ was observed in the substrate supplemented with maize meal followed by boiled wheat (20.0 d). Moreover, days to spawn run in boiled wheat was statistically at par with that of groundnut cake $(20.5 \mathrm{~d})$ and no additives
(20.9 d). Longest duration of spawn run (24.1 d) was noticed in the substrate added with chicken manure. Similar trend was observed in days to pin head formation. Minimum days taken for first harvest $(37.1 \mathrm{~d})$ was recorded from the substrate supplemented with maize meal followed by the treatment without additives (39.0 d).

Yield of mushroom per bag varied from $1106.7 \mathrm{~g}$ to $1266.7 \mathrm{~g}$. Highest yield of mushroom (1266.7 g) was obtained from the substrate supplemented with groundnut cake. Yield of mushroom per bag supplemented with chicken manure (1220.0 g), bengal gram $(1223.3 \mathrm{~g})$ and maize meal $(1210.0 \mathrm{~g})$ were statistically at par with the highest yielder i.e. supplemented with groundnut cake. But, yield from bags without any additives was the lowest $(1106.7 \mathrm{~g})$ among all treatments included in the experiment. Moreover, production of mushroom from bag without additives was statistically at par with that of boiled wheat (1170.0 g), wheat bran (1130.0 g) and rice bran $(1113.3 \mathrm{~g})$.

Benefit and cost (B: $\mathrm{C}$ ) ratio of additives were calculated to find the economic feasibility among all other treatments in the experiment. The calculated B: $\mathrm{C}$ ratio of eight different treatments varied from 1.26 to 1.38 . It was interesting to observe that, the $\mathrm{B}$ : $\mathrm{C}$ ratio of mushroom bag without any additives was highest (1.38) followed by rice bran (1.36). However, B: C ratio of bag (with groundnut cake) producing highest yield was 1.32. It was also noticed that bags with maximum yield (with bengal gram and maize meal) resulted lowest B: C ratio i.e. 1.27 and 1.26 respectively.

The data on morphological characters of mushroom harvested from bags, supplemented with different additives are presented in table 2. The morphological characters (pileus diameter, stipe length and stipe diameter) of mushrooms varied 
depending upon the application of additives. Maximum pileus diameter $(141.1 \mathrm{~mm})$ was recorded in the mushroom harvested from bags supplemented with groundnut cake which was significantly superior to that of bengal gram $(134.3 \mathrm{~mm})$ and maize meal (130.5 mm). Maximum stipe length was observed in the mushroom added with chicken manure $(179.3 \mathrm{~mm})$ which was at par with that of groundnut cake $(178.2 \mathrm{~mm})$ and boiled wheat $(177.5 \mathrm{~mm})$. Similarly, stipe length of mushrooms harvested from bengal gram $(175.1 \mathrm{~mm})$, wheat bran $(173.2 \mathrm{~mm})$ and maize meal $(172.6 \mathrm{~mm})$ were at par with each other and significantly lower from the maximum stipe length. But, maximum stipe diameter of mushroom was observed from boiled wheat $(85.9 \mathrm{~mm})$ added bags which were at par with that of maize meal (84.6 $\mathrm{mm})$ and bengal gram $(83.7 \mathrm{~mm})$.

Table.1 Evaluation of different additives on productivity of Calocybe indica (Pooled)

\begin{tabular}{|c|c|c|c|c|c|c|c|c|}
\hline $\begin{array}{l}\text { Sl. } \\
\text { No. }\end{array}$ & Additives & $\begin{array}{l}\text { Days to } \\
\text { spawn } \\
\text { run }\end{array}$ & $\begin{array}{l}\text { Days to } \\
\text { pin head } \\
\text { initiation }\end{array}$ & $\begin{array}{c}\text { Days to } \\
1^{\text {st }} \\
\text { harvest }\end{array}$ & BE (\%) & $\begin{array}{c}\text { Average } \\
\text { numbers of } \\
\text { fruit bodies/ } \\
\text { bag }\end{array}$ & $\begin{array}{l}\text { Yield } \\
\text { (g)/ 1.5 } \\
\text { kg dry } \\
\text { straw }\end{array}$ & $\begin{array}{l}\text { B:C } \\
\text { ratio }\end{array}$ \\
\hline 1 & Wheat bran & 22.1 & 32.4 & 41.5 & 75.3 & 10.3 & 1130.0 & 1.28 \\
\hline 2 & Boiled wheat & 20.0 & 30.1 & 42.0 & 78.0 & 10.5 & 1170.0 & 1.30 \\
\hline 3 & Rice bran & 22.5 & 33.0 & 43.3 & 74.2 & 10.2 & 1113.3 & 1.36 \\
\hline 4 & Maize meal & 17.5 & 28.0 & 37.1 & 80.7 & 10.9 & 1210.0 & 1.26 \\
\hline 5 & Bengal gram & 22.6 & 32.5 & 42.1 & 81.6 & 10.9 & 1223.3 & 1.27 \\
\hline 6 & Groundnut cake & 20.5 & 29.9 & 40.2 & 84.4 & 11.4 & 1266.7 & 1.32 \\
\hline 7 & Chicken manure & 24.1 & 36.5 & 45.6 & 81.3 & 11.0 & 1220.0 & 1.33 \\
\hline \multirow[t]{3}{*}{8} & No additives & 20.9 & 30.5 & 39.0 & 73.8 & 10.1 & 1106.7 & 1.38 \\
\hline & $\mathrm{SE}(\mathrm{m}) \pm$ & 0.4 & 0.4 & 0.4 & 2.0 & 0.3 & 29.8 & \\
\hline & $\mathrm{CD}(0.05)$ & 1.1 & 1.2 & 1.1 & 5.7 & 0.8 & 85.1 & \\
\hline
\end{tabular}

Table.2 Effect of additives on morphology of Calocybe indica (pooled)

\begin{tabular}{|c|l|c|c|c|}
\hline $\begin{array}{c}\text { Sl. } \\
\text { No. }\end{array}$ & \multicolumn{1}{|c|}{ Additives } & $\begin{array}{c}\text { Pileus } \\
\text { diameter } \\
(\mathbf{m m})\end{array}$ & $\begin{array}{c}\text { Stipe } \\
\text { length } \\
(\mathbf{m m})\end{array}$ & $\begin{array}{c}\text { Stipe } \\
\text { diameter } \\
(\mathbf{m m})\end{array}$ \\
\hline $\mathbf{1}$ & Wheat bran & 117.5 & 173.2 & 81.1 \\
\hline $\mathbf{2}$ & Boiled wheat & 123.6 & 177.5 & 85.9 \\
\hline $\mathbf{3}$ & Rice bran & 113.7 & 172.1 & 76.0 \\
\hline $\mathbf{4}$ & Maize meal & 130.5 & 172.6 & 84.6 \\
\hline $\mathbf{5}$ & Bengal gram & 134.3 & 175.1 & 83.7 \\
\hline $\mathbf{6}$ & Groundnut cake & 141.1 & 178.2 & 78.7 \\
\hline $\mathbf{7}$ & Chicken manure & 124.2 & 179.3 & 76.4 \\
\hline $\mathbf{8}$ & No additives & 112.1 & 170.9 & 73.3 \\
\hline & SE(m) & 1.1 & 1.3 & 1.5 \\
\hline & CD $(0.05)$ & 3.2 & 3.6 & 4.4 \\
\hline
\end{tabular}


Various workers reported increase of yield in milky mushroom with application of organic additives. Geeta and Sivaprakasham, 1994 reported application of different additives such as powdered neem cake, cotton seed cake, groundnut cake and mustard cake increase the production of milky mushroom as well as minimise the spawn run. Application of maize meal as additive increases the production of milky mushroom which has already been reported by Purkayatha and Nayak, 1981; Eswaran and Thomas 2003; Alam et al., 2010. Increase in production of milky mushroom with application of boiled wheat over control was due to increase of net inoculum in the substrate (Elayia and Ganesh, 2013). Maximum production of milky mushroom was reported by Mohit et al., (2019) with application of different pulse powders i.e. black gram, cowpea, pea which correlated the present result of bengal gram. There was significant increase in morphometric of mushroom by application of wheat bran may be due to presence of carbohydrate, amino acid and minerals in wheat bran as suggested by Fasidi and Kadiri, 1993. Similar effect might be applicable in case of other supplements used in the experiment. However, benefit cost ratio was maximum in case of without any additives instead of other supplements because of increase in cost of production.

\section{References}

Alam, N., Amin, R., Khair, A. and Lee, T. S. 2010. Influence of different supplements on the commercial cultivation of milky white mushroom, Mycobiology, 38(3):184188.

Elaiya, R.R. and Ganesha, P. 2013. Effect of different substrate supplements on the growth and yield white summer mushroom (Calocybe indica), International Journal of Recent Scientific Research, 4(1):98-101.

Eswaran, A. and Thomas, S. 2003. Effect of various substrates and additives on the sporophore yield of Calocybe indica and Pleurotus eous. Indian Journal of Mushroom XXI (1 \& 2): 8-10.

Fasidi, I. O. and Kadiri, M. 1993. Effect of sporosphore maturity on chemical composition of Volvariella esculenta (Mass) Singer, a Nigerian Mushroom, Die Nahrung. 37(3): 269-273.

Geeta, D. and Sivaprakasam, K. 1994. Effect of different substrates and amendments on cultivation of oyster mushroom. Proceeding National Symposium on Mushroom.p.58.

Mohit, Kumar, A. and Kumar, S. 2019. Effect of different Pulse additives on production and improvement of biological efficiency of milky mushroom (CI-16-02 and CI-1603). International Journal of Chemical Studies, 7(3):4443-4446.

Purkayastha, R. P. and Chandra, A. 1974. New species of edible mushroom from India. Trans. Br. Mycol. Soc., 62, 415-418.

Purkayastha, R.P. and Nayak, D. 1981. Development of cultivation method and analysis of protein of a promising edible mushroom Calocybe indica. Mushroom Science, 11(2):697-713.

\section{How to cite this article:}

Niranjan Chinara and Shyama Sundar Mahapatra 2020. Effect of Different Organic Supplements for Production of Milky Mushroom (Calocybe indica P\&C) in Odisha. Int.J.Curr.Microbiol.App.Sci. 9(07): 2196-2200. doi: https://doi.org/10.20546/ijcmas.2020.907.256 